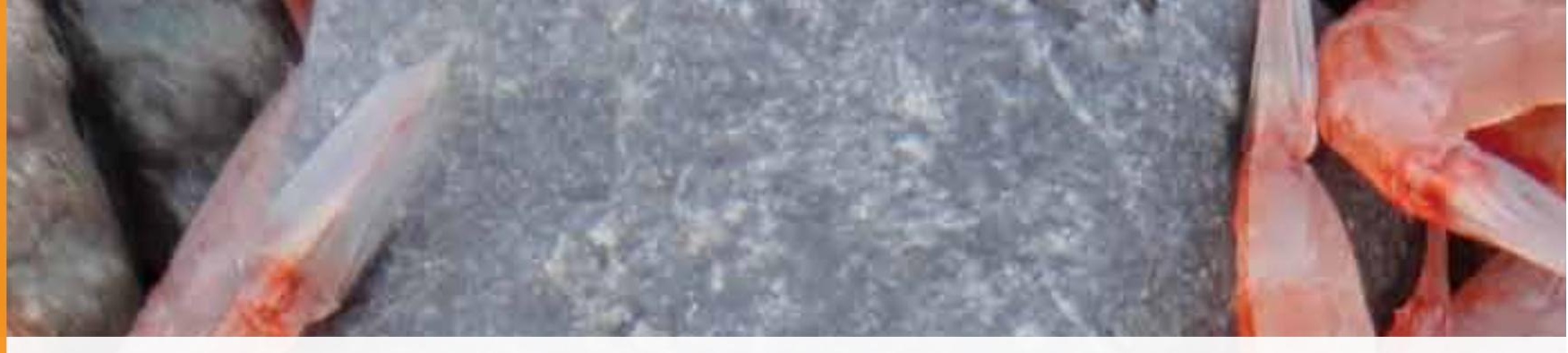

DOI: http://dx.doi.org/10.4322/apa.2015.019

\title{
EFFECT OF DIESEL ON THE ANTIOXIDANT DEFENSE OF THE DIGESTIVE GLAND OF THE ANTARCTIC GASTROPOD Nacella concinna (STREBEL, 1908)
}

\author{
Mariana Feijó de Oliveira ${ }^{*}$, Edson Rodrigues Júnior ${ }^{1}$, Gannabathula Sree Vani², \\ Cecília Nahomi Kawagoe Suda², Lucélia Donatti', Helena Passeri Lavrado³ \& Edson Rodrigues² \\ 'Universidade Federal do Paraná, Departamento de Biologia Celular, Centro Politécnico s/nº, \\ CEP 81990-970, Jd das Américas, Curitiba, PR, Brasil \\ ¿Universidade de Taubaté, Instituto Básico de Biociências, Av. Tiradentes 500, Centro, CEP 12030-180, Taubaté, SP, Brasil \\ 3Universidade Federal do Rio de Janeiro, Departamento de Biologia Marinha, Av. Carlos Chagas Filho 373 , \\ Ilha do Fundão, CEP 21941-902, Rio de Janeiro, RJ, Brasil
}

$$
\text { *e-mail: mari.feijo@bol.com.br }
$$

Abstract: Antarctica is considered the most pristine region in the world, but the increase in human activity has increased the risk of fossil fuel leakage. In this regard, studies with Nacella concinna have proposed this gastropod as sentinel for environmental monitoring. The aim of this study was to evaluate the effect of diesel exposure on the antioxidant defense in the digestive gland of the gastropod Nacella concinna, and the possibility of using these responses as biomarkers of diesel exposure. The activity of the antioxidant defense enzymes glutathione S-transferase, glutathione reductase, superoxide dismutase and catalase, as well as lipid peroxidation and protein carbonylation, as oxidative damage markers, were determined. Among the enzymes analyzed, exposure to diesel significantly modulated only the levels of glutathione S-transferase. Although the oxidative damage marker lipid peroxidation increased in the animals exposed to diesel, protein carbonylation levels remained unchanged. The results suggest that the responses of the antioxidant defense in the digestive gland of the gastropod N. concinna may not be as good biomarkers of diesel exposure as expected.

Keywords: Antarctica, Nacella concinna, Diesel, ROS

\section{Introduction}

The Protocol on Environmental Protection to the Antarctic Treaty grew out of concern about human activity in the continent. In recent decades, navigation on Antarctic waters for fishing, tourism and logistics support to scientific stations has significantly increased the amount of diesel and lubricant oils released into the sea and deposited on the coast by marine currents (Michaud et al., 2004).

The Brazilian Antarctic Station Comandante Ferraz (EACF) is located in King George Island, South Shetlands archipelago, along with scientific installations of 12 countries. The aircraft and ships needed for the logistics of scientific stations use fossil fuel. Martins et al. (2004) found sea sediments contaminated with hydrocarbons derived from fuel oil at the sublittoral near EACF. Studies of
Antarctic organisms from the intertidal and subtidal zones of Marian Cove, on King George Island, also indicate fossil fuel combustion and oil spills as the main pollution sources in the region (Ahn et al., 2004). In this context, the study aim to evaluate the diesel exposure effect on the antioxidant defense in the digestive gland of the local gastropod $N$. concinna, and the possibility of using responses indicators as biomarkers of diesel exposure.

\section{Materials and Methods}

Specimens of intertidal Nacella concinna of 30-40 $\mathrm{mm}$ shell length were manually removed from the rocks during low tide, between January to March of 2011, at Plaza Point, Admiralty Bay, King George Island, Keller 
Peninsula, Antarctica (62 $05^{\prime} 28.8^{\prime \prime}$ S; $58^{\circ} 24^{\prime} 21.3^{\prime \prime}$ W) and taken to EACF labs. After three days of acclimatization at $0^{\circ} \mathrm{C}$ and salinity of $35 \mathrm{psu}$, the limpets were randomly sorted in 3 groups of 10 animals each (control and diesel $1 \%$ and $5 \%$ ). The experimental condition lasted eight days, the water was changed daily and diesel oil added for the experimental groups. The photoperiod was 12 hours without feeding. Only specimens that survived for eight days were dissected. For the biochemical analysis, the digestive gland was separated and immediately frozen in liquid nitrogen. Environmental license for collection and experimentation of $N$. concinna was issued by the Ethical Animal Experimentation Committee of the Federal University of Paraná ( $n^{\circ} 496$ ).

The proportion of $1 \mathrm{~g}$ of tissue to $5 \mathrm{~mL}$ of Tris- $\mathrm{HCl}$ buffer $50 \mathrm{mM}$ ( $\mathrm{pH} 7.4$ ) was homogenated, sonicated centrifuged at $12000 \mathrm{xg}$ for 10 minutes at $4^{\circ} \mathrm{C}$. The supernatants were used for activity of glutathione S-transferase (GST), glutathione reductase (GR), superoxide dismutase (SOD) and catalase (CAT), and for quantification of lipid peroxidation. All enzymatic analyses were conducted at $20^{\circ} \mathrm{C}$. For the analyses of protein carboxylation, the nucleic acids were extracted by addition of streptomycin sulphate of the supernatants. Total protein measurements were performed by the BCA method (bicinchoninic acid), using the QuantiPro BCA Kit, manufactured by Sigma, using bovine albumin as standard. All assays were carried out as described by Feijó-Oliveira (2013).

Statistical analysis was done using Graphpad Prism 5.0. The results are presented as mean \pm SEM (standard error of the mean). Statistical comparison between treatment groups was done using a one way ANOVA, followed by the a posteriori multiple pair wise Tukey test. Homogeneity of variance was checked using Bartlett's test and a log-transformation $\left(\log _{10}\right)$ was applied when required. Differences were considered significant for $p<0.05$.

\section{Results}

The GST levels underwent reduction (but not dose dependent) in exposure to diesel fuel $1 \%$. However, diesel was unable to modulate significantly the GR, SOD, and CAT levels. The LPO levels were positively modulated, and this increase was most evident at $5 \%$ diesel. The levels of PCO were not significantly altered by diesel exposure. A significant difference was observed between LPO levels of the specimens exposed to diesel $1 \%$ and $5 \%$. The results are summarized in Figure 1.

\section{Discussion}

Ansaldo et al. (2005) analyzing the effect of different concentrations of water accommodated fraction of diesel $(0.05 \%$ and $0.1 \%)$ on the levels of antioxidant defense enzymes in the digestive gland of $N$. concinna, found that SOD and CAT levels remained unchanged in almost all experiments, increasing only at the higher concentration of diesel after 48 hours of exposure. The results of these authors are similar to the present study, where diesel did not significantly alter the levels of SOD and CAT in the digestive gland of N. concinna. However, in contrast to our results, they did not find any modulation in GST after exposure to diesel. This may be due to differences in the methodologies used in both studies.

Both LPO and PCO are used as markers of oxidative damage to lipids and proteins, respectively. In the present study, there was no increase of PCO in animals exposed to diesel, although LPO levels increased. In this case, the low levels of PCO may be due to rapid selective removal by proteolytic digestion, to which oxidized proteins are subjected. In cells under oxidative stress, selective degradation of oxidized proteins prevents the formation of large aggregates or potentially toxic fragments, protecting cells from deleterious effects (Shringarpure \& Davies, 2002). Thus, the increase of LPO without a corresponding increase in PCO may be due to rapid degradation of protein carbonyls, and is not incompatible with the existence of oxidative stress in the digestive gland of $N$. concinna. The induction of high levels of GST in bivalves has been associated with its induction as a result of exposure to petroleum. The induction of high levels of GST in Crassostrea braziliana, accompanied by reduced levels of LPO, has reinforced the protective role of GST in exposure to diesel (Lüchmann et al., 2011). Thus, elevated levels of LPO in digestive gland of $N$. concinna, exposed to diesel, are consistent with their inability to positively modulate the levels of GST. In this sense, the inability of $N$. concinna to raise levels of antioxidant defense enzymes (CAT, SOD, GST and GR) may have accelerated oxidative damage caused by reactive oxygen species. 

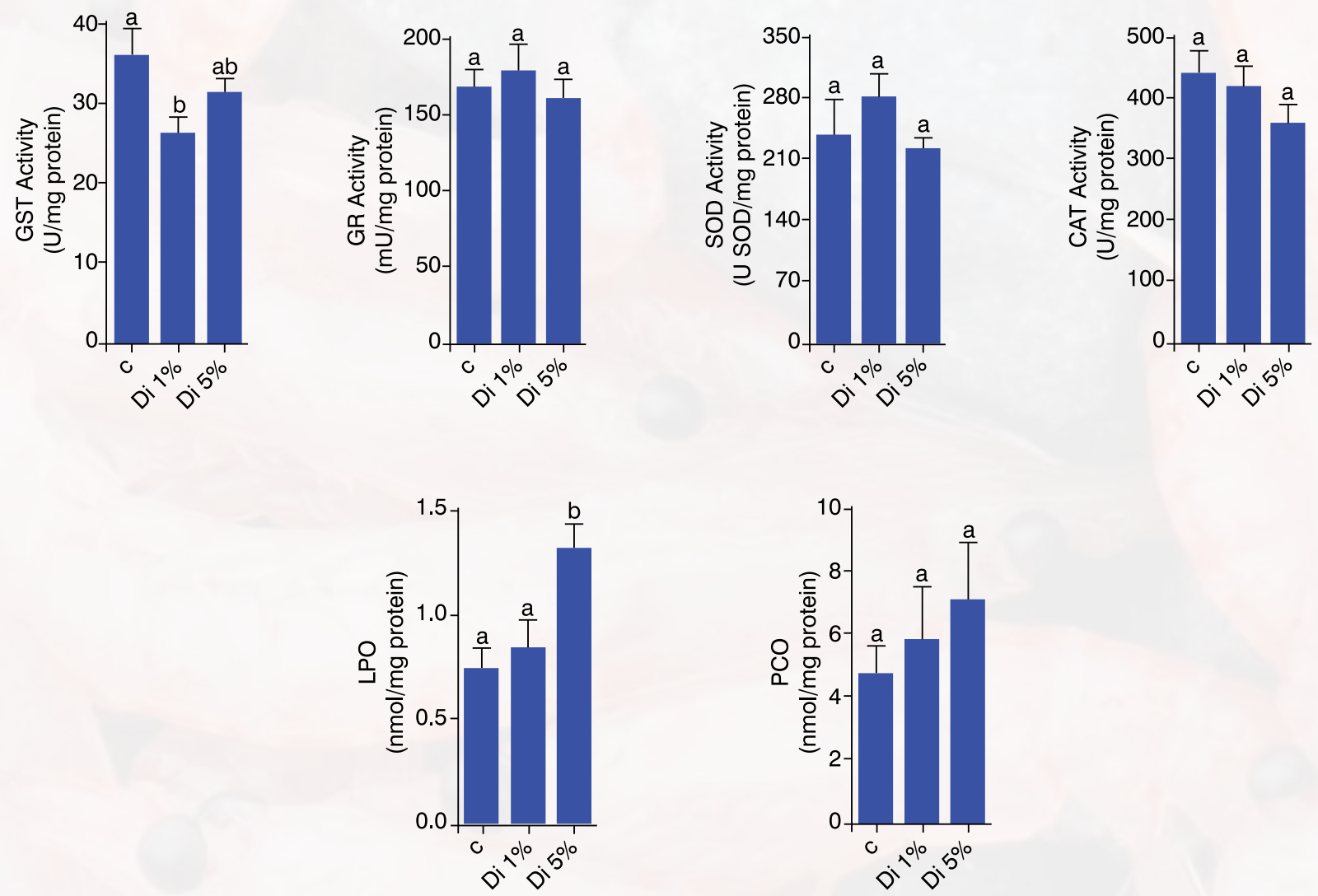

Figure 1. The effect of diesel on the enzymes of the antioxidant defense and non-enzymatic biomarkers of the oxidative stress of the digestive gland of Nacel/a concinna. Different letters indicate significant difference between treatments. The groups are divided into control (C), diesel $1 \%$ (Di $1 \%)$ and diesel $5 \%$ (Di $5 \%$ ).

\section{Conclusion}

Several studies indicate that the antioxidant defense enzymes of invertebrates are good biomarkers of pollution by PAHs. However, in the present study, the levels of GST, GR, SOD and CAT of N. concinna were not good biomarkers of exposure to diesel. While exposure to diesel did not modulate the levels of GR, SOD and CAT of $N$. concinna, the levels of GST in the digestive gland were modulated by the exposure to diesel, but it was not in a dose-response way.

\section{Acknowledgements}

This work contributes to the National Institute of Science and Technology Antarctic Environmental Research (INCTAPA) that receives scientific and financial support from the National Council for Research and Development (CNPq process: $n^{\circ}$ 574018/2008-5) and Carlos Chagas Research Support Foundation of the State of Rio de Janeiro (FAPERJ $n^{\circ}$ E-16/170.023/2008). The authors also acknowledge the support of the Brazilian Ministries of Science, Technology and Innovation (MCTI), of Environment (MMA) and InterMinistry Commission for Sea Resources (CIRM). 


\section{References}

Ahn, I. Y., Chung, K. H., \& Choi, H. J. (2004). Influence of glacial runoff on baseline metal accumulation in the Antarctic limpet Nacella concinna from King George Island. Marine Pollution Bulletin, 49(1-2), 119-127. PMid:15234881, http://dx.doi. org/10.1016/j.marpolbul.2004.03.008

Ansaldo, M., Najle, R., \& Luquet, C. M. (2005). Oxidative stress generated by diesel seawater contamination in the digestive gland of the Antarctic limpet Nacella concinna. Marine Environmental Research, 59(4), 381-390. PMid:15589988. http:// dx.doi.org/10.1016/j.marenvres.2004.06.003

Feijó-Oliveira, M. (2013). Resposta biológica do gastrópode antártico Nacella concinna (Strebel 1908) ao óleo diesel como possível biomarcador de impacto ambiental na zona entre marés. (Dissertação de mestrado em Biologia Celular e Molecular). Universidade Federal do Paraná, Curitiba. PMid:23748964

Lüchmann, K. H., Mattos, J. J., Siebert, M. N., Granucci, N., Dorrington, T. S., Bícego, M. C. et al. (2011). Biochemical biomarkers and hydrocarbons concentrations in the mangrove oyster Crassostrea brasiliana following exposure to diesel fuel water-accommodated fraction. Aquatic Toxicology, 105(3-4), 652-660. PMid:21963596. http://dx.doi.org/10.1016/j. aquatox.2011.09.003

Martins, C. C., Bicego, M. C., Taniguchi, S., \& Montone, R. C. (2004). Aliphatic and polycyclic aromatic hydrocarbons in surface sediments in Admiralty Bay, King George Island, Antarctica. Antarctic Science, 16(2), 117-122. http://dx.doi. org/10.1017/S0954102004001932

Michaud, L., Lo Giudice, A., Saitta, M., De Domenico, M., \& Bruni, V. (2004). The biodegradation efficiency on diesel oil by two psychrotrophic Antarctic marine bacteria during a two-month-long experiment. Marine Pollution Bulletin, 49(5-6): 405409. PMid:15325208. http://dx.doi.org/10.1016/j.marpolbul.2004.02.026

Shringarpure, R., \& Davies, K. J. A. (2002). Protein turnover by the proteasome in aging and disease. Free Radical Biology and Medicine, 32(11), 1084-1089. http://dx.doi.org/10.1016/S0891-5849(02)00824-9 